IIUC STUDIES

ISSN 1813-7733

Vol.- 8, December 2011

(p 215-224)

\title{
The Need of Ijtihad for Sustainable Development in Islam
}

\author{
Arshia Javed $^{*}$ \\ Muhammad Javed $^{* *}$
}

\begin{abstract}
Education has been a central feature of Islam from the very beginning. Our beloved Prophet Muhammad $(P B U H)$ stressed on the acquisition of knowledge and sustainable development of islam. The Quran has given the fundamental education and knowledge but the Muslim scholars must interpret this fundamental knowledge wisely in accordance with the spirit of the time in which we live. Shariah (Islamic law) is subject to interpretation in order to meet the ever-changing needs of society. Muslim jurists and scholars have relied on the well-established process of change known as ijtihad. The process of ijtihad allowed Muslims and Muslim societies to continually adapt in the face of changing societal conditions and new advances in knowledge. However, declaring the shariah complete and announcing of the closure of the gate of ijtihad turns the great thinkers into idols. In this paper, we stressed on the evolutionary aspects of the knowledge \& education (ijtihad) in Muslim society and answered the questions regarding closure of the gate of ijtihad, how important the concept of ijtihad is. As there is an urgent need for the Muslims to realize their failures and deal with the stagnation exist within their minds, how can ijtihad be used to address the needs of muslim societies with reference to contemporary world?
\end{abstract}

Index Terms: Ijtihad, shariah law, gate of Ijtihad, taqlid.

\section{Introduction}

Islam, the fastest growing religion in the world, with over 1.2 billion followers has the astounding capability of adapting to ever changing conditions. Recent international events have intensified interest among

\footnotetext{
* Department of Politics \& IR, IIUniversity, Islamabad, Pakistan.

** School of Computing, Dublin City Univeristy, Dublin, Ireland.
} 
religious leaders, scholars and educational professionals about the way Shariah (Islamic law) is taught \& adopted in Muslim society. [1]. The Quran has given the fundamental education and knowledge but the Muslim scholars must interpret this fundamental knowledge wisely in accordance with the spirit of the time in which we live [2]. Shariah (Islamic law) is subject to interpretation in order to meet the everchanging needs of society. Its guiding principles were designed to protect the individual and the society so that it was not established as a set of fixed rules. To respond to the changing needs of muslim societies, muslim jurists and scholars have relied on the wellestablished process of change, ijtihad. This process is based not only on the holy book (Qur'an) and religious tradition (Sunna), but also on reason, deduction, and prioritization. Ijtihad is practiced by the jurisprudent to discover secondary divine legislation (laws). Ijtihad is defined in different ways [3-5]. A comprehensive definition is given as

the exertion of mental energy in the search for a legal opinion to the extent that the faculties of the jurist became incapable of further effort or in the other words ijtihad is the maximum effort expanded by the jurist to master and apply the principles and rules of usul al- fiqh (legal theory) for the purpose of discovering God's law [3].

The process of ijtihad allowed muslims and muslim societies to continually adapt in the face of changing societal conditions and new advances in knowledge. As it constitutes a bridge between eternally valid divine injunctions and time specific requirement of every age, it is the key to provide an islamic interpretation of modern developments and circumstances. Moreover, it also serves as a mean through which religion can become intricately interwoven with politics [4]. Scholars considered the time, place norms and prevailing conditions while rendering their religious advice and opinions. Ijtihad enabled muslims to be flexible and to learn from other cultures and civilizations. Without the process of ijtihad, a faithful muslim will find himself in a dilemma.

Unfortunately, autocratic behavior of muslim caliphs and rationalist movements lead the muslims to adopt more conservative stance in an attempt to preserve traditional values and institutions. As a result, many scholars became inclined to view ijtihad negatively and it was assumed fit for the muslims to declare the shariah complete, thus 
announced the closure of the gate of ijtihad. This closure led the muslims towards gradual decline from being a superpower to mere disoriented people subjected to humiliation in every field of life only because they stopped questioning and started on a way of blind following (taqlid) and taqlid itself is a symbol of stagnation. Closing the gate of ijtihad turns the great thinkers into idols [5].

Muslim thinkers from 18th to 20th century were on the view that to regain the glory and to revive islam, muslims must return to critical thinking and a process of adapting to the modern world and the key to these remains in the practice of ijtihad. But, a number of questions arise here (which are also the areas of consideration in this paper) i.e.

- How can the door of ijtihad be reopened?

- Was it really closed?

- Why did muslims scholars raise the subject of the gate of ijtihad?

- Why did muslim become fail in performing ijtihad effectively to meet the challenges of the contemporary world?

- How can it be used to address the needs of muslim societies with reference to contemporary world?

The rest of the paper is structured as follows. A brief history of Ijtihad is given in Section 2. In Section 3, we argue and discuss about the closure of the gate of Ijtihad in the light \& viewpoints of the great Islamic scholars. Section 4 describes about the necessity of Ijtihad in this contemporary world and we end with some concluding remarks.

\section{Ijtihad and its Brief History}

Ijtihad derived from the Arabic word jahada which means "attempts". The term is used particularly in such occasions where hard ship and efforts are involved. According to Imam Ghazali (a philosopher of islamic golden age), ijtihad means to expand once capacity in certain matter and use it to the utmost. Some scholars have defined it as a mean of expanding to the fullest capacity by the mujtahid in seeking the knowledge of shariah. The perfect definition of ijtihad would mean that one has spent so much effort in pursuit of the knowledge of shariah that further pursuit is humanly impossible [5].

Sayf al-Din al- Amidi (a jurist of the shafi school) define ijtihad as the total expenditure of effort in the search for an opinion as to any legal rule in such a manner that an individual senses (within himself) an 
ability to expand further effort [6]. The definition emphasizes that the search must be total, involving the jurist utmost energies. If the jurist has failed to discover evidence, which he was quite capable of discovering, his opinion is void.

The practice of ijtihad remained the norm rather than the exception during the era of Khulifa-e-Rashideen and the lifetime of the companions of the Prophet (PBUH). These companions of Prophet Muhammad (PBUH) were in a position to interpret and apply the principles of sunnah with the least possible error. Therefore, ijtihad that was performed by the Prophet's companions is not subject to reinterpretation.

But unfortunately, few centuries ago the activity of ijtihad had been exploited, which lead the muslim scholars to a rigid reading of the Quran. This was mainly because of the behavior of rationalist movement and muslim caliphs, which became increasingly autocratic, as they began to use their power negatively to fulfill their interests. So, as a result many scholars became to view ijtihad negatively. In [3], author mentions that scholars of all schools felt that all essential question had been thoroughly discussed and finally settled and a consensus gradually established itself to the effect from that time onwards no one might be deemed to have the necessary qualification for independent reasoning in law, and that all future activity would have to be confined to the explanation, application, and at the most, interpretation of the doctrine as it had been laid down once and for all.

From the moment the gate of ijtihad considered to be closed in the views of many scholars, the concept of taqlid (stagnation, blind imitation) was introduced in the world of islam. In [7], author expressed that the exercise of independent judgment in early days produced a rich flowering of scientific activity and discovery but as soon as the gate of ijtihad was subsequently closed, a long period followed during which muslim science consisted of entirely of compilation and repetition.

\section{The Gate of Ijtihad}

There is a contradiction among some muslims and western scholars of islam about the notion that gate of ijtihad was closed or not. Traditionally, Sunni muslims believed that revelation stopped with the death of the prophet and the gate of ijtihad (independent interpretation) closed in the tenth century [4]. Some scholars believe that gate of 
ijtihad was closed in thirteenth century rather than in tenth century. With reference to this, muslim scholars were on a view that this was mainly because of the belief that all the answers were already there and all that was needed to follow and obey [7]. But the movement for the revival of ijtihad began with Ibn-Taymmiyah who negated the concept of taqlid as for him taqlid was deviation from the Quran and Sunnah and was therefore an innovation, even polytheistic [5]. Some other scholars of Islam from 18th to 20th century also believed on the closure of the gate of ijtihad and stressed that it must be reopened in order to meet the challenges that were faced by Islam. For example, Shah Waliyullah remarks that " $i$ am convinced for various reasons that today the door of ijtihad is completely closed"[8]. Taqlid led to the stagnation of mind and made muslims incapable of defining themselves according to the conditions prevailing in the world. Another great Muslim scholar Jamul al- Din Afghani with reference to this notion was on a view that the gate of ijtihad is not closed at all, it is not only a duty but also a right to implement the principle of the Quran on the problem of our time continuously. Its refutation is tantamount to taqlid and stagnation [5].

According to Allama Muhammad Iqbal, in his famous publication Reconstruction of Religious thought in Islam [9], he declared that the closing of the door of ijtihad is pure fiction suggested partly by crystallization of legal thought in islam and partly by the intellectual laziness which, especially in the period of spiritual decay, turns great thinkers into idols. If some of the later doctors have upheld this fiction, modern islam is not bound by this voluntary surrender of intellectual independence. To prove his point, he gave an example of Turkey. The act of Turkish assembly by which they change caliphate from an individual and personal institution into a collective one by delegating the power of caliphate to the assembly. He calls this reform as an ijtihad. Iqbal admire the Turks for this great achievement as they were the first muslims to abandon taqlid.

On the other hand western scholars like Hallaq, W. Montgomery Watt, and H.A.R. Gibb have challenged the notion of "closure of ijtihad". They believe that the gate of ijtihad could not really be closed and the tradition of ijtihad was never abandoned.

There are so many explanations about the notion of closing of the gate of ijtihad. As for some scholars, closing of gate of ijtihad meant that there is no possibility of establishing of new school of thought and the 
opening of the door of ijtihad meant to found a new school of law. In fact, the door of ijtihad was never closed, so for as working within the limits of a certain school of law was concerned. Historically, this term developed only as a statement to express the historical fact that after a particular period no new school of law can be established. However, it is perceived by some scholars like Hallaq that the door of ijtihad is not closed, as there is a possibility of forming another school of law other than the four-school of thought, which should have the capability to solve the problem of the modern time faced by islam, as the traditional school of thought emphasizes on taqlid.

It is perceived by some scholars that in the past the door of ijtihad was considered closed because it provided immunity to the shariah against the interference of government and rationalist movement. There is another explanation or perception behind this notion that the practice of ijtihad was abandoned because the qualification requires for its practice were made so immaculate and rigorous and were set so high that they were humanly impossible to fulfill [6]. But these notions are also rejected by Hallaq as he argue that the vast bulk of fatwas (legal opinion) that appeared from fourth to tenth century prove that activity of ijtihad was never stopped.

Hallaq in his article presented four points to prove that the gate of ijtihad was not closed in theory nor in practice [5].

- Jurist capable of ijtihad existed all the time

- Ijtihad was used in developing the positive law after the formation of schools

- Up to $500 \mathrm{AH}$, there was no phrase 'insidad bab alijtihad' or any other expressions pointing towards closure

- The controversy about closure of gate of ijtihad and extinction of Mujtahid prevented jurists reaching a consensus to that effect

In the relevant literature on this subject, from fourth/tenth century it is clear that the gate was not closed. In practice and theory, the activity of ijtihad was uninterrupted throughout the history, as there is no phrase which is available about insidad bab al- ijtihad or any other expression that may allude to the notion of the closure. But the confusion emerged in this area when the term of ijtihad came to be defined with reference to schools of law by ignoring its actual meaning and associate number of secondary meaning with it. 
The concept of modern state also becomes another important reason which brought changes in the activity of ijtihad. According to this concept, the right of making and enforcing law vested with the state and its institution alone. Individuals are entitled to express their opinions, but opinions became law only after they had been enacted by the legislature.

According to Joseph Schacht (a british-german professor of arabic and islam), some muslim scholars raised the subject of the gate of ijtihad only because by the beginning of the fourteenth century, islamic law had been elaborated in detail and thus muslim scholars came to the conclusion that all essential questions had been thoroughly discussed and finally settled [10]. Schacht believed that this was the basic reason behind the raising of the question of who was qualified to practice ijtihad and who was not and above all, the reason behind the perception of closure of gate of ijtihad.

In reality the activity of ijtihad was never stopped. The underline reason behind this is, the practice of ijtihad was declared to be a religious duty incumbent upon all qualified jurist whenever a new case appears. The survival of ilm and in turn of the shariah depends on continued functioning of ijtihad and this is one of the important reasons because of which ijtihad is practiced by muslim scholars in the past without any break (although it was done at smaller scale). Blocking the gate of ijtihad would have meant for muslims a partial and imperfect mastery of ilm and thus a deficient and incomplete shariah. Inability to extend the precept of sharia to newly arising problems would have also meant that Islam was utterly inadequate. Thus, activity of ijtihad was done in the past without any break, but on the other hand, muslims performed this activity on a small scale or it was done on individual or domestic level. Infect from the last two centuries, efforts of muslim scholars to deal with stagnation and to upraise their conditions with the help of critical thinking were not remarkable at all. This is one of the important reasons behind the assumption that in the past gate of ijtihad was closed.

\section{Ijtihad and Contemporary World}

The world of Islam after about six centuries of intellectual advancement, during which it produced a most illustrious galaxy of scholars, began to decline. With reference to this, Afghani was on a view that the blame for our decline does not lie elsewhere; it lies on us because we ceased to be dynamic as the Quran wanted us to be. 
Muslims became static and began to rest on our laurels. The Quran called on us to engage in a continuous struggle. While we began to think that we had reached to the limit and began to rest intellectually, while others were marching on [11]. The Holy Prophet (PBUH) had given the basic principle only to the muslims, which are in the Holy Quran and His own example (Sunnah). He had directed the muslims to use their judgment in working out details according to the changing circumstances and rising exigencies. For this, as the benefit of the whole ummah lies in the activity of ijtihad, Allah promised a reward to a mujtahid. As there is hadith with reference to this that "when a judge makes ijtihad and reaches a correct conclusion, he receive a double reward; and if his conclusion is incorrect, he still receive a reward".

The decline of muslims started gradually from superpower to mere disoriented people and becomes subject to humiliation in every field of life and this is only because they stopped questioning and started on a way of blind following or in other words they stopped critical thinking in order to meet the challenges of the modern world. As human society is a developing entity and human actions, relationships and activities are ever increasing and ever expanding. Many things are invented that were not existed before. Therefore, the process of ijtihad is responsible for catering to all the needs of the human society and to provide answers to all questions, which may arise. Without the process of ijtihad, many human activities are difficult to develop in the sphere of an Islamic life. One question arises here, why it becomes difficult for the muslims in contemporary world to perform activity of ijtihad with its full dynamics? so that it could bring solution of all those problems faced by the muslims from the last few years. Perhaps there are so many reasons, which are responsible for ineffectiveness of ijtihad in the present era. As for example, abolishment of caliphate in its true sense and the emergence of the concept of the nation states becomes huge hurdle in the path of this activity. As because of these two reasons a question arises in the world of islam, who have authority to perform ijtihad? Some says that ijtihad cannot be performed effectively in the present time because no one fulfills the requirements of mujtahid in the present time.

The old interpretations no longer provide suitable answers to the difficult questions faced by the muslim world. Thus, muslims must try to deal with the stagnation existing within their minds. They must try to reinterpret (but within some limitations), which can give them suitable answers with reference to contemporary challenges. As it seems 
impossible for the muslims to get rid of all existing problems and go back to the caliphate, which can resolve the issue of authority. For the better performance of ijtihad Afghani recommended that ulma should establish regional centers in the various countries where ijtihad could be exercised for the guidance of common man. These regional centers should be connected with a global center, which may be established in any one of the holy places. According to him the representative of various centers may foregather to exercise ijtihad for the whole Ummah and will prepare it to withstand foreign challenges [5].

\section{Concluding Remarks}

Islam the fastest growing religion in the world, with over 1.2 billion followers has the astounding capability of adapting to ever changing conditions. The basic aim of islamic shariah is to provide guidance and way of life to its followers. The star of islam was at its rise and islam crossed borderers from Asia to Africa and then Europe, when the tradition of ijtihad was at its height. However, selfish behavior of rulers, rationalist movement and abolishment of caliphate in its true sense lead the muslims towards gradual decline because they stopped questioning and critical thinking. This ultimately led the muslims from superpower to mere disoriented people subjected to humiliation in every field of life. As with reference to this Abduh was on a view that decline of muslim societies is because of their ignorance and misunderstanding of the faith and because of taqlid (blind imitation) [4]. Thus, to regain their eminence power and glory, muslims must return to critical thinking and the key to this remain in the practice of ijtihad. This is the only way through which muslims can make themself compatible with the existing world and can cope with the challenges presented by contemporary world. Without the tool of ijtihad, the gap between islamic theory or aspirations and contemporary reality or constraints becomes impossible to bridge. 


\section{References}

1. Zia, R.:Transmission of Values in Muslim Countries: Religious Education and Moral Development in School Curricula. In CERC Studies in Comparative Education, Springer Netherlands. pp. 119-134, volume 18, number 3,2007.

2. Al-Attas, F.: Interview on Islam and Education. In Islamic Perspective Journal, Volume 1, Number 2, pages: 7-16, 2009.

3. Hallaq, W.B.: Was the gate of ijtihad closed? In Journal of Middle East Studies. volume 16, number 1, pages 3-41, 1984.

4. Rahnema, A.: Pioneers of Islamic Revival. Zed Books Ltd Publishers, London, UK edition, 1995.

5. Mas'ud M.K.: Iqbal's reconstruction of Ijtihad. 2nd edition, Iqbal Academy Publishers, Lahore, Pakistan, 2003.

6. Weiss, B.: Interpretation in Islamic Law: The Theory of Ijtihad. In The American Journal of Comparative Law., volume 26, number 2, pages 199-212, 1978.

7. Lewis, B.: The Muslim Discovery of Europe. 2nd edition, London Redwood Burn Ltd. Publishers, UK. pages 230, 1982.

8. Jalbani, G.N.: Teaching of ShahWaliyullah of Delhi. 2nd edition, Ashraf Printing Press, Lahore, Pakistan, pages 199, 1967.

9. Iqbal, M.: Reconstruction of Religious Thought in Islam. 2nd edition, Ashraf Printing Press, Lahore, Pakistan, pages 178, 1982.

10. Hallaq, W. B.: On the origin of the controversy about the existence of mujtahid and the gate of ijtihad. In Journal of Studies Islamica, volume 24, number 63, pages 129-141, 1986.

11. Malik, C.: God and Man in Contemporary Islamic Thought. Centennial Publishers, Beirut, pages 228, 1972. 